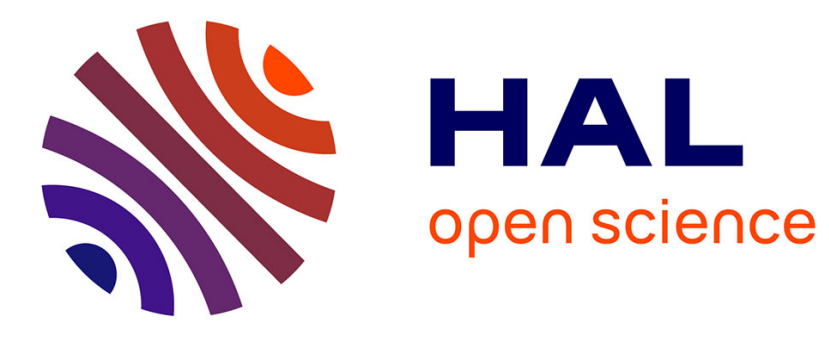

\title{
Control of stoichiometry and morphology in polycrystalline V2O3 thin films using oxygen buffers
}

Jonathan Rupp, Benoît Corraze, Marie-Paule Besland, Laurent Cario, Julien

Tranchant, Dirk Wouters, Rainer Waser, Etienne Janod

\section{To cite this version:}

Jonathan Rupp, Benoît Corraze, Marie-Paule Besland, Laurent Cario, Julien Tranchant, et al.. Control of stoichiometry and morphology in polycrystalline V2O3 thin films using oxygen buffers. Journal of Materials Science, 2020, 55 (30), pp.14717-14727. 10.1007/s10853-020-05028-0 . hal-02932318

\section{HAL Id: hal-02932318 \\ https://hal.science/hal-02932318}

Submitted on 18 Dec 2020

HAL is a multi-disciplinary open access archive for the deposit and dissemination of scientific research documents, whether they are published or not. The documents may come from teaching and research institutions in France or abroad, or from public or private research centers.
L'archive ouverte pluridisciplinaire $\mathbf{H A L}$, est destinée au dépôt et à la diffusion de documents scientifiques de niveau recherche, publiés ou non, émanant des établissements d'enseignement et de recherche français ou étrangers, des laboratoires publics ou privés. 
Title:

Control of stoichiometry and morphology in polycrystalline V2O3 thin films using oxygen buffers

Authors:

J. A. J. Rupp ${ }^{1, *}$, B. Corraze ${ }^{3}$, M.-P. Besland ${ }^{3}$, L. Cario ${ }^{3}$, J. Tranchant $^{3}$, D. J. Wouters ${ }^{1}$, R. Waser $^{1,2}$, E. Janod ${ }^{3}$

\section{Affiliations:}

1) RWTH Aachen (Germany)

Jonathan A. J. Rupp, rupp@iwe.RWTH-Aachen.de ${ }^{*}$ Corresponding Author

Dr. Dirk J. Wouters, wouters@iwe.RWTH-Aachen.de

Prof. Dr. Rainer Waser: waser@iwe.RWTH-Aachen.de

2) PGI-7 FZ Jülich (Germany)

Prof. Dr. Rainer Waser: waser@iwe.RWTH-Aachen.de

3) Institut des Matériaux Jean Rouxel (IMN) Université de Nantes, CNRS (France)

Dr. Benoît Corraze : benoit.corraze@cnrs-imn.fr

Dr. Marie-Paule Besland : marie-paule.besland@cnrs-imn.fr

Dr. Etienne Janod : etienne.janod@cnrs-imn.fr

Dr. L. Cario : laurent.cario@cnrs-imn.fr

Dr. J. Tranchant : julien.tranchant@cnrs-imn.fr

Key words:

Vanadium Sesquioxide, V2O3, Stoichiometry, Oxygen Buffer, Buffer Couple 


\section{Abstract:}

In this work, we investigate the influence of low temperature reduction conditions ( $873 \mathrm{~K}$ ) by different oxygen buffers on the off-stoichiometry of polycrystalline $\mathrm{V}_{2} \mathrm{O}_{3}$ thin films. Vanadium oxide thin films (thickness $300 \mathrm{~nm}$ and $100 \mathrm{~nm}$ ) have been grown by reactive sputtering and have been annealed in a buffered atmosphere subsequently. Buffer couples were chosen throughout the stability range of $\mathrm{V}_{2-y} \mathrm{O}_{3}(y \leq 0.03)$ by the use of different oxygen buffer combinations, namely $\mathrm{Ni} / \mathrm{NiO}, \mathrm{Fe} / \mathrm{Fe}_{3} \mathrm{O}_{4}, \mathrm{Cr} / \mathrm{Cr}_{2} \mathrm{O}_{3}$ and $\mathrm{Mn} / \mathrm{MnO}$. Thin films have been characterized by scanning electron microscopy, X-ray diffractometry and low temperature electrical transport measurements. Upon decreasing the oxygen partial pressure, the mean grain size of $\mathrm{V}_{2} \mathrm{O}_{3}$ decreases systematically from $45 \pm 20 \mathrm{~nm}$ with a high porosity to $27 \pm 10 \mathrm{~nm}$ without porosity. The most favourable reduction conditions have been identified for Fe- and Cr-based couples. Moreover, all four buffer couples exhibit high transition temperatures of the IMT transition (110 - $155 \mathrm{~K}$ ) close to ideally stoichiometric $\mathrm{V}_{2} \mathrm{O}_{3}(y<0.005)$ as well as large changes in resistance at the transition (three to five orders of magnitude). This oxygen buffer method hence provides a valuable synthesis method of highly stoichiometric polycrystalline $\mathrm{V}_{2} \mathrm{O}_{3}$ thin films with technological relevance.

\section{Introduction:}

The binary system of vanadium and oxygen consists of various Magnéli $\mathrm{V}_{n} \mathrm{O}_{2 n-1^{-}}$and Wadsley $\mathrm{V}_{\mathrm{n}} \mathrm{O}_{2 \mathrm{n}+1}$ phases [1]. Most of these phases show remarkable electronic and magnetic phase transitions [2]. Amongst them, corundum-type $\mathrm{V}_{2} \mathrm{O}_{3}$ undergoes an Insulator-to-Metal transition (IMT) at $155 \mathrm{~K}$. This transition occurs between an antiferromagnetic (insulating) monoclinic phase at low temperature and a paramagnetic (conducting) rhombohedral corundum phase at high temperature [3]. Upon decreasing temperature, the phase change is 
accompanied by a drop of the $c / a$ ratio as well as an increase in volume of about $1.2 \%$ [4]. At room temperature, substituting vanadium with more than 1.1 at. $\%$ chromium induces a transition from paramagnetic metal to paramagnetic Mott insulator while retaining the same corundum structure. Applying physical pressure on $\left(\mathrm{V}_{1-\mathrm{x}} \mathrm{Cr}_{\mathrm{x}}\right)_{2} \mathrm{O}_{3}$ leads to the inverse IMT and restores the metallic state. More interestingly, the Mott insulator-to-metal transition can not only be driven by pressure or temperature [4] but also by an electric field [5]. Therefore, this archetype Mott-Hubbard-insulator is of strong interest for application in resistively switching devices [6] and neuromorphic circuits [7][8]. However, very accurate control of stoichiometry is required to achieve a well-defined Mott-insulating state that matches the required halffilling criteria [9]. Such a control of the vanadium-oxygen ratio is crucial in thin films on which further electrical applications will be based. For instance, deviations of stoichiometry in $\mathrm{V}_{2-\mathrm{y}} \mathrm{O}_{3}$ as low as $y=0.03$ indeed lead to an absence of the low temperature IMT [10]. To reach low oxygen content compounds under thermodynamic control, reduction experiments can be performed in reducing atmospheres such as $\mathrm{CO} / \mathrm{CO}_{2}$ or $\mathrm{Ar} / \mathrm{H} 2$ [11], usually at high temperatures above $1000 \mathrm{~K}$. For instance, Shivashankar et al. investigated the controlled formation of non-stoichiometric $\mathrm{V}_{2-\mathrm{y}} \mathrm{O}_{3}$ across the pure-phase window at a reduction temperature of $1473 \mathrm{~K}$ in $\mathrm{CO} / \mathrm{CO}_{2}$ atmosphere with subsequent quenching [10]. A huge reduction of the vanadium point defect density (decreasing $y$ from 0.02 down to 0.007 ) with a concomitant increase of transition temperature from $10 \mathrm{~K}$ to $155 \mathrm{~K}$ could be achieved by lowering the oxygen partial pressure towards the equilibrium line of $\mathrm{VO} / \mathrm{V}_{2} \mathrm{O}_{3}$. An alternative method to control the oxygen partial pressure can be achieved by an oxygen buffer method [12] that similarly imposes an oxygen partial pressure with a metal - metal oxide buffer couple (see experimental part). Here we show that reduction with an oxygen buffer can be successfully applied to control the stoichiometry of polycrystalline $\mathrm{V}_{2} \mathrm{O}_{3}$ thin films even for low 
annealing temperatures such as $873 \mathrm{~K}$. Four different buffer couples (BC) have been chosen to aim at four different stoichiometry values in the range of phase-pure $\mathrm{V}_{2} \mathrm{O}_{3}$. Based on thermochemical data [13], one might expect that the vanadium vacancies $y$ in $\mathrm{V}_{2-y} \mathrm{O}_{3}$ decreases with the $\mathrm{BC}^{\prime} \mathrm{S}$ according to $\mathrm{y}_{\mathrm{Ni} \mathrm{NiO}}>\mathrm{y}_{\mathrm{Fe}-\mathrm{Fe} 3 \mathrm{O} 4}>\mathrm{y}_{\mathrm{Cr}-\mathrm{Cr} 2 \mathrm{O} 3}>\mathrm{y}_{\mathrm{Mn}-\mathrm{MnO}}$. On the contrary, we found that for thin films, reduction annealing with the mentioned oxygen buffers does not follow the thermodynamic principle of single crystals reduced at high temperatures anymore.

\section{Experimental:}

One promising way to succeed a very precise control of oxygen point defects is to exploit the condition of thermodynamic equilibrium for metal-oxide reactions. Each dynamic equilibrium between a metal and a corresponding oxide is defined by its Gibbs free energy $\Delta G$ that consists of an enthalpy $\Delta H$ and entropy $\Delta S$ terms. In this case, referring to the Ellingham approximation, both are considered temperature-independent. The change in $\Delta G$ can then be related to the oxygen partial pressure $p\left(\mathrm{O}_{2}\right)$ in a direct way :

$$
\Delta G=\Delta H-T \Delta S=-\mathrm{R} T \ln p\left(\mathrm{O}_{2}\right)
$$

where $\mathrm{R}$ denotes the gas constant, $T$ the temperature and $p\left(\mathrm{O}_{2}\right)$ the oxygen partial pressure in thermodynamic equilibrium between the two solids. With given reaction enthalpies and entropies from literature (Table 1), the equilibrium oxygen partial pressure was straightforwardly calculated for four different oxygen buffer associations within the window of off-stoichiometric $\mathrm{V}_{2} \mathrm{O}_{3}$. Amorphous vanadium oxide thin films (thickness $300 \mathrm{~nm}$ and $100 \mathrm{~nm}$ ) have been deposited on silica by RF-reactive sputtering from a one inch vanadium target. The oxygen partial pressure $p\left(\mathrm{O}_{2}\right)$ was adjusted by the flux ratio of two mass flow controllers: one with pure argon $(90 \mathrm{sccm})$ and one with a mixture of argon and oxygen in the ratio 99:1 (10 sccm). This allowed control of the $p\left(\mathrm{O}_{2}\right)$ in a few 10 nbar range. The relatively 
low oxygen partial pressure value of 10 nbar was used to reach a V:O ratio close to $2: 3$ in the amorphous films prior to reducing annealing (where the measured average value constituted $\left.2: 4^{[14]}\right)$. The used power of $P=50 \mathrm{~W}$ and the process pressure of $p=10 \mu$ bar resulted in a deposition rate of $q=3.3 \mathrm{~nm} / \mathrm{min}$. Thin films were subsequently placed inside silica tubes with a metal and oxide powder couple at a pressure of $p<10^{-3}$ mbar to provide a constant V:O stoichiometry ratio independent of temperature. After sealing, the tubes were annealed in a tubular furnace at a temperature of $873 \mathrm{~K}$, with a heating rate of $300 \mathrm{~K} / \mathrm{h}$, an annealing time of $1 \mathrm{~h}$ at $873 \mathrm{~K}$, and finally passive free cooling down to room temperature with a rate of $\sim 100 \mathrm{~K} / \mathrm{h}$. Figure 1 displays the theoretical equilibrium oxygen partial pressures for the four selected buffer couple reactions between metals and oxides with respect to temperature. Buffer couples were chosen to introduce an increasing concentration of vanadium defects as a result of an increase of oxygen partial pressure from $\mathrm{Mn}$ - based to $\mathrm{Cr}$-/Fe-/ $\mathrm{Ni}$-based $\mathrm{BCs}$. Metal and oxide quantities were weighted according to the reaction equation's mole masses. Morphology was determined by scanning electron microscopy (SEM) images with a Zeiss "DSM982 GEMINI" microscope. Lateral grain sizes were determined by the line section method. Surface vacancy area (100 nm layers) and surface crack area (300 nm layers) were determined by ImageJ 1.51d with a contrast filter. X-ray diffraction (XRD) patterns were recorded in Bragg-Brentano geometry with a Bruker X-Ray diffractometer. Lattice parameters were extracted by le Bail refinement with JANA software from X-ray diffraction (XRD) patterns. To investigate electrical transport characteristics at low temperatures in four-point configuration, a closed-cycle helium circuit cryostat "Omniplex DE210" from ARS was used. Transition temperatures of the IMT were determined for the cooling and heating branch at the turning point of the derivative logarithmic resistance versus inverse temperature $(\mathrm{d}(\ln R) / \mathrm{d}(1 / T))$. 


\section{Results:}

\subsection{Morphology}

Figure 2 shows morphological changes of $\mathrm{V}_{2} \mathrm{O}_{3}$ thin films throughout the stoichiometry window. As-deposited amorphous $100 \mathrm{~nm}$ thick films already present a rough surface with relatively large particles up to $36 \mathrm{~nm}$ in diameter (Figure 2a1\&2) whereas $300 \mathrm{~nm}$ thick films show a relatively dense columnar structure (Figure $2 a 3 \& 4$ ). The $100 \mathrm{~nm}$ thick film annealed with $\mathrm{BC} \mathrm{Ni/NiO}$ exhibits a grain size of $d_{\mathrm{Ni}, 100}=39 \pm 14 \mathrm{~nm}$ with visible surface pinholes (Figure $2 \mathrm{~b} 1 \& 2$ ). The grain size is comparable to the pristine amorphous state (Figure $2 \mathrm{a} 1 \& 2$ ). For a higher thickness of $300 \mathrm{~nm}$ (Figure 2b3\&4), grain size increases slightly $\left(d_{\mathrm{Ni}, 300}=44 \pm 18 \mathrm{~nm}\right)$ compared to $100 \mathrm{~nm}$ thick thin films and the cross section image shows a more porous bulk morphology as compared to the pristine amorphous dense columnar structure (Figure 2a3\&4). For $\mathrm{BC} \mathrm{Fe} / \mathrm{Fe}_{3} \mathrm{O}_{4}$ (Figure $2 \mathrm{c} 1 \& 2$ ) and a thickness of $100 \mathrm{~nm}$, grain size $\left(d_{\mathrm{Fe}, 100}=23 \pm 7 \mathrm{~nm}\right)$ as well as pinhole size decreases compared to $\mathrm{Ni} / \mathrm{NiO}$, quantitatively described by Figure $2 \mathrm{f} \& \mathrm{~g}$. With respect to the $100 \mathrm{~nm}$ films reduced by $\mathrm{Fe} / \mathrm{Fe}_{3} \mathrm{O}_{4}$, an increased grain size is obtained for $300 \mathrm{~nm}\left(d_{\mathrm{Fe}, 300}=36 \pm 15 \mathrm{~nm}\right)$ thick layers (Figure $\left.2 \mathrm{c} 3 \& 4\right)$. In addition, a considerable part of the surface is covered with formed cracks (Figure 2c3). Layers synthesized with a $\mathrm{BC} \mathrm{Cr} / \mathrm{Cr}_{2} \mathrm{O}_{3}$ (Figure $2 \mathrm{~d} 1 \& 2$ ) show a smaller average grain size $\left(d_{\mathrm{cr}, 100}=20 \pm 8 \mathrm{~nm}\right)$ with few smaller pinholes for $100 \mathrm{~nm}$ layers as compared to $100 \mathrm{~nm}$ thick layers annealed with $\mathrm{BC} \mathrm{Fe} / \mathrm{Fe}_{3} \mathrm{O}_{4}$ (Figure 2c1\&2). Corresponding $300 \mathrm{~nm}$ thick layers (Figure $2 \mathrm{~d} 3 \& 4$ ) still form cracks to a lesser extent compared to $\mathrm{BC} F e / \mathrm{Fe}_{3} \mathrm{O}_{4}$ (Figure $2 \mathrm{c} 3 \& 4$ ) and present only a slightly higher grain size than $100 \mathrm{~nm}$ layers $\left(d_{c r, 300}=23 \pm 7 \mathrm{~nm}\right)$. Lastly, BC $\mathrm{Mn} / \mathrm{MnO}$ (Figure 2e1\&2) results in a very fine grain size of $\left(\mathrm{d}_{\mathrm{Mn}, 100}=15 \pm 2 \mathrm{~nm}\right)$ with a 
considerably higher roughness compared to $\mathrm{BC} \mathrm{Cr} / \mathrm{Cr}_{2} \mathrm{O}_{3}$ which is reflected by a spatial variation in contrast. For $300 \mathrm{~nm}$ layers (Figure 2e3\&4), a flatter surface with increased grain size is visible compared to $100 \mathrm{~nm}$ thin films $\left(d_{M n, 300}=26 \pm 10 \mathrm{~nm}\right)$. Yet, in this case, broad hills grow on the surface (instead of cracks as found for $\mathrm{BCs} \mathrm{Fe} / \mathrm{Fe}_{3} \mathrm{O}_{4}$ and $\mathrm{Cr} / \mathrm{Cr}_{2} \mathrm{O}_{3}$ ). To sum up, grain sizes (Figure $2 \mathrm{f}$ ) and free volume (Figure $2 \mathrm{~g}$ ) decreases equally with the sequence of buffer couples for both thicknesses.

\subsection{Crystal Structure and Lattice Parameters}

All films were characterized by XRD analysis. XRD records from $100 \mathrm{~nm}$ thick films exhibit diffraction peaks with weak intensity, not suitable to accurately resolve lattice parameters. Thus, cell parameters were extracted from XRD patterns obtained for $300 \mathrm{~nm}$ thick $\mathrm{V}_{2} \mathrm{O}_{3}$ thin films (Figure 3a). For the $\mathrm{V}_{2} \mathrm{O}_{3}$ thin film obtained by buffer couple $\mathrm{Ni}-\mathrm{NiO}$, black arrows denote an (unknown) formed secondary phase. Table 2 summarizes the obtained lattice parameter values and fitting parameters. In Figure $3 b$, the variation of unit cell parameters as function of $\mathrm{BC}$ type is plotted (where bulk $\mathrm{V}_{2} \mathrm{O}_{3}$ values are indicated by horizontal lines). For all buffer couples, the $c / a$ ratios (orange star) deviate from the bulk value except for $\mathrm{Mn} / \mathrm{MnO}$ where the $c / a$ ratio matches the ideal $c / a$ ratio of $\mathrm{V}_{2} \mathrm{O}_{3}$. Furthermore, with $\mathrm{BC} \mathrm{Ni} / \mathrm{NiO}$ for offstoichiometric $\mathrm{V}_{2-y} \mathrm{O}_{3}, c$ parameter (green triangle) and cell volume (blue hexagon) are compressed by $0.05 \AA$ and $1 \AA^{3}$, respectively, whereas the $a$ parameter (red square) is slightly expanded by $0.01 \AA$. With $\mathrm{BC}$ to lower $p\left(\mathrm{O}_{2}\right)$ (left to right in Figure $3 b$ ), c-parameter and cell volume relax to bulk values whereas the a-parameter expands even more up to the $\mathrm{BC} \mathrm{Cr}$ $\mathrm{Cr}_{2} \mathrm{O}_{3}$. For $\mathrm{BC} \mathrm{Mn/MnO}$, parameters $a$ and $c$ as well as the cell volume are reduced compared to bulk. 


\subsection{Electrical Transport Characteristics}

With low temperature electrical transport measurements, the insulator-to-metal transition of $\mathrm{V}_{2} \mathrm{O}_{3}$ was investigated for $300 \mathrm{~nm}$ thick films (Figure 4a) as well as $100 \mathrm{~nm}$ thick films (Figure 4b). For all buffer couple combinations, both thicknesses exhibit exactly the same trends with sharp transition behaviour as well as an increase of room temperature resistivity towards the equilibrium line of $\mathrm{V}_{2} \mathrm{O}_{3} / \mathrm{VO}$, indicating a high reproducibility of the reduction process in this thickness range. The lowest transition temperatures between $90 \mathrm{~K}$ and $140 \mathrm{~K}$ were found for the two extreme $\mathrm{BC}$ 's, namely $\mathrm{Mn}-\mathrm{MnO}$ and $\mathrm{Ni}-\mathrm{NiO}$. Besides, $\mathrm{Fe}-\mathrm{Fe}_{2} \mathrm{O}_{3}$ and $\mathrm{Cr}-$ $\mathrm{Cr}_{2} \mathrm{O}_{3}$ revealed the highest transition temperatures between $110 \mathrm{~K}$ and $157 \mathrm{~K}$. In the case of a $300 \mathrm{~nm}$ thick $\mathrm{V}_{2} \mathrm{O}_{3}$ film annealed with $\mathrm{BC} \mathrm{Fe}-\mathrm{Fe}_{3} \mathrm{O}_{4}$, the largest resistance change is observed with five to six orders of magnitude, in good agreement with the transition magnitude obtained for single crystals [4]. In these experiments, $300 \mathrm{~nm}$ thick films exhibit a slightly broader hysteresis than the $100 \mathrm{~nm}$ ones. While varying the nature of the $\mathrm{BC}$, room temperature resistivity increases continuously by roughly one order of magnitude from $4.7 \cdot 10^{-}$ ${ }^{4} \Omega \cdot \mathrm{cm}(300 \mathrm{~nm} \mathrm{Ni} / \mathrm{NiO})$ to $3 \cdot 0 \cdot 10^{-3} \Omega \cdot \mathrm{cm}(300 \mathrm{~nm} \mathrm{Mn} / \mathrm{MnO})$. To be able to identify the differences between reduction processes in the transition region in more detail, the negative differential resistance versus inverse temperature is plotted versus temperature (Figure 4c). Interestingly, one can identify two maxima for each branch in the $300 \mathrm{~nm}$ thick film reduced by $\mathrm{BC} \mathrm{Ni+NiO} \mathrm{(blue} \mathrm{plot)} \mathrm{and} \mathrm{even} \mathrm{three} \mathrm{maxima} \mathrm{for} \mathrm{the} \mathrm{two} \mathrm{samples} \mathrm{reduced} \mathrm{by} \mathrm{BC} \mathrm{Fe}+\mathrm{Fe}_{3} \mathrm{O}_{4}$ (green plot). Generally, for each thickness, one would expect only one maximum for cooling as well as heating owing the hysteresis linked to the first order transition, as found for BCs $\mathrm{Cr}+\mathrm{Cr}_{2} \mathrm{O}_{3}$ and $\mathrm{Mn}+\mathrm{MnO}$. Figure $4 \mathrm{~d}$ summarizes the development of transition temperatures for used buffer couples and thicknesses. Lower thicknesses of $100 \mathrm{~nm}$ exhibit higher transition temperatures with an increase between $5 \mathrm{~K}$ and $25 \mathrm{~K}$. An increasing transition temperature 
can be found in the case of $\mathrm{Mn}, \mathrm{Ni}$ to $\mathrm{Fe}$ and $\mathrm{Cr}$, with split transition temperatures into multiple maxima for Fe and Ni.

\section{Discussion:}

As can bee seen in the experimental section, highly stoichiometric thin films have been obtained for all oxygen buffer combinations. Clearly, by changing the Gibbs free energy of the reduction process with $\mathrm{BCs}$, an (equivalently associated) decrease in vanadium deficiency does not hold for polycrystalline thin films as observed in single crystals [10]. In the following sections, results are interpreted in more detail for each oxygen buffer couple individually.

\subsection{Buffer Couple Ni-NiO}

As determined by SEM imaging (Figure $2 \mathrm{~b}$ ), thin films obtained by $\mathrm{BC}$ Ni-NiO revealed the largest grain size for $100 \mathrm{~nm}$ thick films as well as the largest void volume among the investigated samples (Figure $2 \mathrm{~b} 1 \& 2$ ). In addition, $300 \mathrm{~nm}$ thick thin films preserve the same rather large grain sizes and exhibit a porous microstructure (Figure 2b3\&4). XRD-patterns of $300 \mathrm{~nm}$ thick thin films (Figure 3a) confirm a corundum-type $\mathrm{V}_{2} \mathrm{O}_{3}$ structure. From the phase diagram [1], one could also expect $\mathrm{V}_{3} \mathrm{O}_{5}$ to be a stable phase during the reduction process, since only a slightly higher $p\left(\mathrm{O}_{2}\right)$ is needed to stabilize such phase. Apparently, a secondary phase is formed (marked by arrows) which could not be indexed by a single known vanadium oxide phase. Thermodynamically, the most stable phase in ambient atmosphere after completion of the reduction process would be $\mathrm{VO}_{2}[15]$ on large time scales (and oxides with comparable stoichiometry such as $\mathrm{V}_{6} \mathrm{O}_{11}$ ). Through a deeper analysis of the XRD-pattern, slight impurity phase is found with weak diffraction peaks at $29.2^{\circ}, 47.3^{\circ}$ and $48.3^{\circ}$ that may correspond to (-126), (2010) and (-136) planes of a minor phase fraction of $\mathrm{V}_{6} \mathrm{O}_{11}$ [16]. Yet, additional peaks at $57.1^{\circ}$ and $58.6^{\circ}$ cannot be associated to this phase. In any case, a higher 
oxidized phase is to be expected for the given $\mathrm{BC} \mathrm{Ni-NiO}$. Both phases $\mathrm{V}_{3} \mathrm{O}_{5}$ and $\mathrm{V}_{6} \mathrm{O}_{11}$ belong to the family of Magnéli phases $\mathrm{V}_{\mathrm{n}} \mathrm{O}_{2 \mathrm{n}-1}$ and differ only by a change in sheared crystallographic planes [16]. The exposure to air after reduction might lead to a surface oxidation and appearance of $\mathrm{V}_{2} \mathrm{O}_{3}$ grains exhibiting a shell constituted of oxide phases close to $\mathrm{VO}_{\mathrm{x}^{\sim 2}}$ (such as $\mathrm{V}_{6} \mathrm{O}_{11}$ ) as already detected in the case of epitaxially grown $\mathrm{V}_{2} \mathrm{O}_{3}$ [17][18]. Indeed, the high porosity (as observed in SEM images) can further promote surface oxidation more deeply within the "bulk" thin film with a larger surface area exposed to air. Lattice parameter values of $\mathrm{V}_{2} \mathrm{O}_{3}$ crystallites (Figure $3 \mathrm{~b}$, left) show a c-parameter, $c / a$ ratio as well as cell volume $V$ lower than the bulk value; only the $a$-parameter is slightly higher than the corresponding bulk value [19] (straight line). Since the $c / a$ ratio deviates from bulk values (which should be constant if related only to the deviation in vanadium deficiency [19]), one can conclude that compressive internal stress is present in the thin film. Low temperature electrical transport measurements (Figure 4a) reveal a broad transition temperature range between $100 \mathrm{~K}$ and $165 \mathrm{~K}$ for $300 \mathrm{~nm}$ thick films with two sharp variations (better visible in the derivative of the resistance in Figure $4 \mathrm{c}$ dark blue). For $100 \mathrm{~nm}$ thin films (Figure 4b), only a single slope maximum is present (Figure 4c light blue). A possible explanation for the two maxima could be the difference between grain boundaries and void regions in $300 \mathrm{~nm}$ thin films where different stress states exist between more relaxed grains in vicinity of voids and more compressed grains in denser regions. However, one may not expect two sharp maxima but rather a continuous distribution of the transition temperature region. Another explanation favoured by the authors refers to the possible formation of a $\mathrm{V}_{6} \mathrm{O}_{11}$ phase, which has a bulk transition temperature of $177 \mathrm{~K}[20]$. In combination with the $\mathrm{V}_{2} \mathrm{O}_{3}$ transition temperature at $155 \mathrm{~K}$ [4], theory would predict two maxima separated by a temperature shift of $22 \mathrm{~K}$ where we observe a variation of $18 \mathrm{~K}$ and $25 \mathrm{~K}$, for cooling and heating curve, respectively. Then, the shift of both transition 
temperatures of $\mathrm{V}_{2} \mathrm{O}_{3}$ and $\mathrm{V}_{6} \mathrm{O}_{11}$ could be related to a compressive stress within the film as revealed by the compressed cell volume (Figure $3 b$ ). The fact that an (almost) ideal stoichiometric $\mathrm{V}_{2} \mathrm{O}_{3}$ phase with a quite high transition temperature can be synthesized with $\mathrm{BC} \mathrm{Ni-NiO} \mathrm{(inducing} \mathrm{a} \mathrm{relatively} \mathrm{high} \mathrm{oxygen} \mathrm{partial} \mathrm{pressure)} \mathrm{is} \mathrm{rather} \mathrm{surprising} \mathrm{since}$ thermodynamics would predict a highly non-stoichiometric thin film with a transition temperature close to $10 \mathrm{~K}$ [10]. Like many other binary metal oxides, $\mathrm{NiO}$ is known to provide a non-stoichiometry regime that changes with temperature [21]. Therefore, this effect may shift the iso-composition line towards more reducing conditions. Apparently, the deviation towards reducing conditions occuring during the iso-compositional cooling process with $\mathrm{BC}$ $\mathrm{Ni}-\mathrm{NiO}$ favours a nearly stoichiometric $\mathrm{V}_{2} \mathrm{O}_{3}$ phase (in contrast to a quenching process of single crystals after the use of high reduction temperatures [10]). Consequently, one could also relate the two maxima in transition slope to a change in $\mathrm{BC}$ conditions with a stoichiometric $\mathrm{NiO}$ phase at the maximum reduction temperature (belonging to the lower maximum) and a final $\mathrm{Ni}^{2+}{ }_{1-3 x} \mathrm{Ni}^{3+}{ }_{2 x} \mathrm{O}$ phase at room temperature (belonging to the higher maximum). However, no color change could be observed after the reduction process, i.e. from green colour of a stoichiometric $\mathrm{NiO}$ towards grey/black colour of a nonstoichiometric compound. Moreover, this explanation would need to rely on strongly deviating reduction conditions between the two thicknesses since no peak splitting was observed for the thinner film (100 nm thick) reduced by $\mathrm{BC} \mathrm{Ni} / \mathrm{NiO}$.

\subsection{Buffer Couple Fe- $\mathrm{Fe}_{3} \mathrm{O}_{4}$}

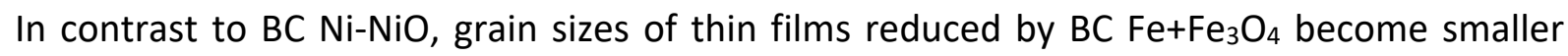
(Figure 2f) along with the decrease of "void" volume for $100 \mathrm{~nm}$ thick films in form of pin holes (Figure 2c1\&2). The smaller grain size obtained at lower oxygen partial pressure is likely to be a side effect of stronger out-diffusion of oxygen from the initially amorphous film. The 
stronger excorporation of oxygen could favor the nucleation density during crystallization which may hinder grain growth and recrystallization in the reduction process. At the same time, for $300 \mathrm{~nm}$ thick films (Figure 2c3\&4), no void regions are visible anymore. Instead, "free volume" is revealed by extended cracks at the surface. These cracks typically reach several hundred nanometers deep into the thin film (Figure $2 \mathrm{c} 2$ for a $300 \mathrm{~nm}$ film). Contrary to $\mathrm{BC} \mathrm{Ni}-$ $\mathrm{NiO}$, the $300 \mathrm{~nm}$ thick films do not show any XRD-resolvable secondary phases except corundum $\mathrm{R} \overline{3} \mathrm{C}_{2} \mathrm{O}_{3}$ (Figure 3a). Cell parameters are similar to those obtained with $\mathrm{BC} \mathrm{Ni}-\mathrm{NiO}$ with compressed values except for a slight tensile strained as revealed by the $a$-parameter value (Figure 3b). However, the resistance jump observed at transition is roughly one order of magnitude higher for $300 \mathrm{~nm}$ thick films (five orders of magnitude instead of four orders of magnitude for $\mathrm{BC} \mathrm{Ni/NiO,} \mathrm{Figure} 4 b$ ) and the transition itself shows three maxima in slope (Figure 4c). A possible explanation for this slight dispersion of the transition temperature is an inhomogeneous distribution of vanadium vacancies $y$ within grains of the $\mathrm{V}_{2-y} \mathrm{O}_{3}$ phase. This would happen if the trajectory of the $p\left(\mathrm{O}_{2}\right)$ - temperature imposed by the $\mathrm{Fe}-\mathrm{Fe}_{3} \mathrm{O}_{4}$ couple (indicated by the green line in Figure 1), does not strictly correspond to a constant $y$ value in $\mathrm{V}_{2-y} \mathrm{O}_{3}$. As a consequence, a gradient between the grain core and its shell would arise during the cooling part of the annealing process (see inset in Figure 1), which can be "frozen" at low temperature as soon as the kinetics of vanadium diffusion becomes too slow. Such a coreshell gradient in vanadium vacancies $y$ could therefore easily explain the distribution of transition temperature shown in Figure 4c. Moreover, this scenario is consistent with the different transition temperatures observed in $100 \mathrm{~nm}$ and $300 \mathrm{~nm}$ thick films annealed with $\mathrm{Fe}-\mathrm{Fe}_{3} \mathrm{O}_{4}$, since their strongly different grain size $(23 \mathrm{~nm}$ for the $100 \mathrm{~nm}$ thick film, against $37 \mathrm{~nm}$ for the $300 \mathrm{~nm}$ thick one) could lead to a different final distribution of vanadium vacancies within each grain. 


\subsection{Buffer Couple $\mathrm{Cr}-\mathrm{Cr}_{2} \mathrm{O}_{3}$}

Thin films reduced by $\mathrm{BC} \mathrm{Cr}-\mathrm{Cr}_{2} \mathrm{O}_{3}$ exhibit the same trend towards smaller grain size and void \& crack volume compared to $\mathrm{BC} \mathrm{Ni-NiO}$ or $\mathrm{Fe}^{-\mathrm{Fe}_{3} \mathrm{O}_{4}}$ (Figure $2 \mathrm{~d}, \mathrm{f}, \mathrm{g}$ ). As checked by XRD pattern, only pure phase corundum $\mathrm{R} \overline{3} \mathrm{c} \mathrm{V}_{2} \mathrm{O}_{3}$ is detected (Figure 3a). In contrast to all other $\mathrm{BCs}$, the cell volume is expanded and the $c$ parameter only exhibits a slight compression. Thus, one expects the transition temperature to be raised which is confirmed by the highest transition temperature for $300 \mathrm{~nm}$ thick films (147 K in Figure 4a). In analogy, $100 \mathrm{~nm}$ thick films exhibit a transition temperature similar to the one obtained after reduction by $\mathrm{Fe}^{-} \mathrm{Fe}_{3} \mathrm{O}_{4}$ (Figure $4 \mathrm{~b}$ ). However, the resistivity jump at transition is reduced by over one order of magnitude. Apparently, the quite dense nanostructure with small crystallites (average size $<20 \mathrm{~nm}$ ) might not be sufficient to provide the required space of $1 \%$ free volume that is necessary to enable the volume expansion of the low temperature phase transition [4]. Only surface-related grains might provide enough free volume close to cracks and pinholes (Figure 2g). For both thicknesses of $100 \mathrm{~nm}$ and $300 \mathrm{~nm}$, a sharp single maximum of the transition slope is present (Figure 4c) which resembles a pure and dense corundum $\mathrm{V}_{2} \mathrm{O}_{3}$ phase as well as a uniform distribution of stress. The very controlled conditions are likely to be a consequence of the $\mathrm{Cr}$ $\mathrm{O}$ phase diagram where only pure $\mathrm{Cr}_{2} \mathrm{O}_{3}$ is a thermodynamically stable phase ${ }^{[22]}$. Lacking intermediate phases thus prevents any shift of the iso-composition line.

\subsection{Buffer Couple Mn-MnO}

An obvious difference of $100 \mathrm{~nm}$ thick films reduced by $\mathrm{BC} \mathrm{Mn}-\mathrm{MnO}$ is an increased roughness (Figure 2e1) and a highly dense thin film with smallest grain diameters of $\sim 12 \mathrm{~nm}$. In contrast to the previously discussed BCs, $300 \mathrm{~nm}$ thick films do not exhibit any cracks or pinholes in surface. Instead, hill growth is visible at the surface. Grain sizes and "void" volume drop to the 
minimum for both thicknesses compared to all other BCs. XRD analysis confirm the presence of a pure $\mathrm{V}_{2} \mathrm{O}_{3}$ phase belonging to $\mathrm{R} \overline{3}$ c-type (Figure $2 \mathrm{a}$ ) where diffraction peaks are significantly broadened and fully coherent with a small grain size of $26 \pm 10 \mathrm{~nm}$. Compared to stoichiometric bulk $\mathrm{V}_{2} \mathrm{O}_{3}$, this film displays the same $c / a$ ratio, but a lower unit cell volume, i.e. a compressive internal stress. According to ref. [19], this could indicate an "oxygen nonstoichiometry": $z=0.044$ in the (erroneous) formulation $\mathrm{V}_{2} \mathrm{O}_{3+z}$, or rather to vanadium deficiency $y=0.029$ in the correct $\mathrm{V}_{2-\mathrm{y}} \mathrm{O}_{3}$ description. (Figure $2 \mathrm{~b}$ ). This would lead to a transition temperature as low as $10 \mathrm{~K}$ and thus a metallic behavior [10]. Obviously, this scenario is not coherent with the observed transition temperature above $100 \mathrm{~K}$ and the resistivity jump at transition of three to four orders of magnitude, respectively (Figure 4a\&b). Another possible explanation could be the extreme reducing conditions imposed by the $\mathrm{Mn}$ $\mathrm{MnO}$ buffer couple leading to oxygen vacancies and an effective composition $\mathrm{V}_{2} \mathrm{O}_{3+x}(x>0)$. As for the case of well-established vanadium vacancies in $\mathrm{V}_{2-\mathrm{y}} \mathrm{O}_{3}$, such oxygen vacancies would lead to the reduction of the unit cell volume, without changing the $c / a$ ratio, as we observed experimentally.

\subsection{On the Effect of Buffer Couples}

The discussion above shows that thermodynamic principles of high temperature reduction of bulk samples cannot easily be transferred to thin films with relatively low reduction temperatures. For instance, the calculated oxygen partial pressures along the cooling path are below any countable static oxygen partial pressures. Apart from the four studied buffer couples, another oxide-oxide combination $\mathrm{Ce}_{2} \mathrm{O}_{3}-\mathrm{CeO}_{2}$ (where the equilibrium line of oxygen partial pressure lies between $\mathrm{BCs}$ Fe and $\mathrm{Cr}$ ) resulted in comparable electrical transport properties (transition temperature of $100 \mathrm{~K}$ and resistance jump at transition of five orders of magnitude, not shown) even though unknown $\mathrm{CeO}_{x}$ phases could be detected in the oxygen 
buffer after the annealing process. These results raise the need of further theoretical investigations for these technologically relevant synthesis conditions, especially due to the astonishing broad success of the method.

\section{Conclusion}

Polycrystalline $\mathrm{V}_{2} \mathrm{O}_{3}$ thin films (thickness $300 \mathrm{~nm}$ and $100 \mathrm{~nm}$ ) have been synthesized under controlled thermodynamic conditions at low temperatures and strongly deviate from high temperature reduction experiments on single crystals. Changing the Gibbs free energy by different buffer couples affected morphological features but resulted in comparable electrical properties. Oxygen buffers close to the equilibrium line of $\mathrm{VO} / \mathrm{V}_{2} \mathrm{O}_{3}(\mathrm{Mn}-\mathrm{MnO})$ and $\mathrm{V}_{2} \mathrm{O}_{3} / \mathrm{V}_{3} \mathrm{O}_{5}$ (Ni-NiO) induced a possible oxygen deficiency and secondary phase precipitation, respectively. By lowering of the Gibbs free energy with different oxygen buffers, grain sizes and void regions shrink which is explained by a stronger removal of oxygen during the reduction process. Finally, the $\mathrm{Fe}-\mathrm{Fe}_{3} \mathrm{O}_{4}$ and $\mathrm{Cr}-\mathrm{Cr}_{2} \mathrm{O}_{3}$ oxygen buffers led to the strongest changes in resistance at the IMT's up to five orders of magnitude and highest transition temperatures close to the one of stoichiometric $\mathrm{V}_{2} \mathrm{O}_{3}$. The $\mathrm{Cr}-\mathrm{Cr}_{2} \mathrm{O}_{3}$ buffer couple is particularly appealing since it leads to very homogeneous $\mathrm{V}_{2} \mathrm{O}_{3}$ films with abrupt insulator to metal transitions. $100 \mathrm{~nm}$ thick films exhibited identical trends with slightly reduced hysteresis width, higher transition temperature and a smaller change of resistance at the transition. These results may have a strong impact on design rules for the miniaturization of resistive Mott-switching devices towards their physical limits.

\section{Acknowledgements}

J. A. J. Rupp would like to thank M. Querré and T. Hennen for fruitful discussions. Low temperature electrical transport measurements as well as X-ray diffraction experiments have 
been perfomed at the Insitute des Matériaux (IMN Nantes/FR). Furthermore, J. A. J. Rupp greatly acknowledges the Deutsche Forschungsgemeinschaft DFG for funding this project in the Sonderforschungsbereich (SFB) 917.

\section{Compliance with ethical standards}

\section{Conflict of Interest}

The authors declare no conflict of interests.

\section{Bibliography}

[1] H. A. Wriedt: "The O-V (Oxygen Vanadium) System", Bull. Alloy Phase Diagrams 1989, 10, 271. DOI: $10.1007 / \mathrm{BF} 02877512$.

[2] G. Stefanovich, A. Pergament, D. Stefanovich: "Electrical switching and Mott transition in $\mathrm{VO}_{2}$ ", J. Phys.: Condens. Matter 2000, 12, 8837. DOI: 10.1088/0953-8984/12/41/310.

[3] R. E. Word, S. A. Werner, W. B. Yelon: "Spin waves in vanadium sesquioxide $\mathrm{V}_{2} \mathrm{O}_{3}$ ", J. Phys. Rev. B 1981, 23, 3533. DOI: 10.1103/PhysRevB.23.3533

[4] D. B. McWhan, T. M. Rice, J. P. Remeika: "Metal-Insulator Transition in $\left(\mathrm{V}_{1-\mathrm{x}} \mathrm{Cr}_{\mathrm{x}}\right)_{2} \mathrm{O}_{3}$ ", Phys. Rev. Lett. 1970, 23, 1384. DOI: 10.1103/PhysRevB.2.3734.

[5] P. Stoliar, L. Cario, E. Janod, B. Corraze, C. Guillot-Deudon, S. Salmon-Bourmand, V. Guiot, J. Tranchant, M. Rozenberg: "Universal Electric Field-Driven Resistive Transition in NarrowGap Mott Insulators", Adv. Mat. 2013, 25, 23. DOI: 10.1002/adma.20130113.

[6] M. Querré, E. Janod, L. Cario, J. Tranchant, B. Corraze, V. Bouquet, S. Deputier, S. Cordier, M. Guilloux-Viry, M.-P. Besland: "Metal-insulator transitions in $\left(\mathrm{V}_{1-\mathrm{x}} \mathrm{Cr}_{\mathrm{x}}\right)_{2} \mathrm{O}_{3}$ thin films deposited by reactive direct current magnetron co-sputtering", Thin Solid Films 2015, 617, 56-62. DOI: 10.1016/i.tsf.2015.12.043.

[7] P. Stoliar, J. Tranchant, B. Corraze, E. Janod, M.-P. Besland, F. Tesler, M. Rozenberg, L. Cario: "A Leaky-Integrate-and-Fire Neuron Analog Realized with a Mott Insulator", Adv. Func. Mat. 2017, 1604740, 1. DOI: 10.1002/adfm.201604740.

[8] C. Adda, B. Corraze, P. Stoliar, P. Diener, J.Tranchant, A. Filatre-Furcate, M. Fourmigué, D. Lorcy, M.-P. Besland, E. Janod, L. Cario: "Mott insulators: A large class of materials for Leaky Integrate and Fire (LIF) artificial neuron", J. Appl. Phys. 2018, 124, 152124. DOI:

$10.1063 / 1.5042756$

[9] E. Janod, J. Tranchant, B. Corraze, M. Querre, P. Stoliar, M. Rozenberg, T. Cren, D. Roditchev, V.T. Phuoc, M.-P. Besland: "Resistive Switching in Mott Insulators and Correlated Systems", Adv. Func. Mat. 2015, 25, 6287. DOI: 10.1002/adfm.201500823. 
[10] S. A. Shivashankar, R. Aragon, H. R. Harrison, C. J. Sandberg, J. M. Honig: "Preparation and Electrical Properties of $\mathrm{V}_{2} \mathrm{O}_{3}$ Single Crystals of Controlled Stoichiometry", J. Electrochem. Soc. 1981, 128, 2472. DOI: 10.1149/1.2127272.

[11] Harold H. Kung (Ed.): "Transition Metal Oxides: Surface Chemistry and Catalysis" 1989 Elsevier, 45, 91. ISBN: 978-0-444-87394-1.

[12] R. J. D. Tilley: "Principles and Applications of Chemical Defects" 1998 CRC Press, $187 \mathrm{ff}$. ISBN: $\underline{9780748739783 .}$

[13] Thomas B. Reed: "Free Energy of Formation of Binary Compounds", MIT Press Cambridge, MA, 1971.

[14] J. A. J. Rupp, M. Querré, A. Kindsmüller, M-P. Besland, E. Janod, R. Dittmann, R. Waser, D. Wouters, „Different threshold and bipolar resistive switching mechanisms in reactively sputtered amorphos undoped and Cr-doped vanadium oxide thin films", J. Appl. Phys. 2018, 123, 044502. DOI: 10.1063/1.5006145.

[15] S. Andersson, L. Jahnberg: "Crystal structure studies on the homologous series $\mathrm{Ti}_{n} \mathrm{O}_{2 \mathrm{n}-1}$, $\mathrm{V}_{\mathrm{n}} \mathrm{O}_{2 \mathrm{n}-1}, \mathrm{Ti}_{\mathrm{n}-2} \mathrm{Cr}_{2} \mathrm{O}_{2 \mathrm{n}-1}$ ", Ark. Kemi. 1963, 21, 413.

[16] H. Horiuchi, N. Morimoto, M. Tokonami: "Crystal structures of $\mathrm{V}_{n} \mathrm{O}_{2 n-1}(2 \leq n \leq 7)$ ", J. Sol. Stat. Chem. 1976, 17, 407. DOI: 10.1016/S0022-4596(76)80011-4.

[17] S. Surnev, G. Kresse, M. G. Ramsey, F. P. Netzer: "Novel Interface-Mediated Metastable Oxide Phases: Vanadium Oxides on Pd(111)", J. Am. Chem. Soc. 2001, 87, 086102-2. DOI: 10.1103/PhysRevLett.87.086102.

[18] A. J. Window, A. Hentz, D. C. Sheppard, G. S. Parkinson, H. Niehus, D. Ahlbehrendt, T. C. Q. Noakes, P. Bailey, D. P. Woodruff: " $\mathrm{V}_{2} \mathrm{O}_{3}(0001)$ Surface Termination: Phase Equilibrium", Phys. Rev. Lett. 2011, 107, 016105. DOI: 10.1103/PhysRevLett.107.016105.

[19] Y. Ueda, K. Kosuge, S. Kachi: "Phase diagram and some physical properties of $\mathrm{V}_{2} \mathrm{O}_{3+x}$

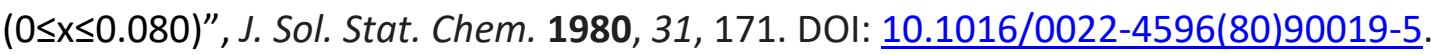

[20] H. Okinaka, K. Nagasawa, K. Kosuge, Y. Bando, S. Kachi, T. Takada: “Electrical Properties of $\mathrm{V}_{6} \mathrm{O}_{11}$ and $\mathrm{V}_{7} \mathrm{O}_{13}$ Single Crystals", J. Phys. Soc. Jap. 1970, 29, 245. DOI:

10.1143/JPSJ.29.245.

[21] P. Dubey, N. Kaurav, R. S. Devan, G. S. Okram, Y. K. Kuo: "The effect of stoichiometry on the structural, thermal and electronic properties of thermally decomposed nickel oxide", RSC Adv. 2018, 8, 5882. DOI: 10.1039/C8RA00157J.

[22] H. Okamoto: "Cr-O (chromium-oxygen", J. Phase Eq. 1997, 18, 402. DOI: 10.1007/s11669-997-0072-0.

[23] M. C. Morris, H. F. McMurdie, E. H. Evans, B. Paretzkin, H. S. Parker, N. C. Natl. Bur. Stand. (U.S.) Monogr. 1983, 25, 20, 108. ICDD 00-034-0187 $\left(\mathrm{V}_{2} \mathrm{O}_{3}\right)$. 


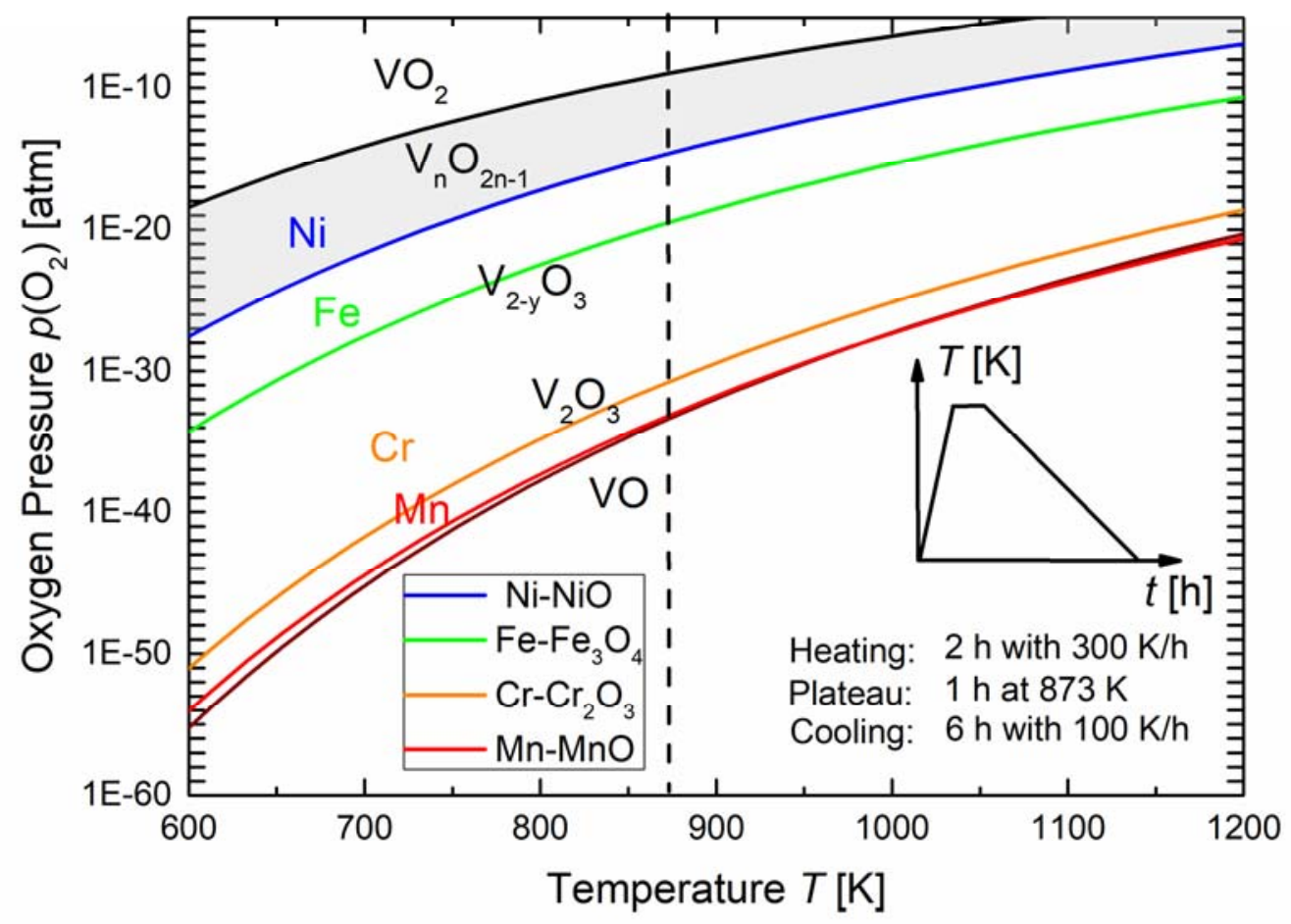

Figure 1: Equilibrium oxygen partial pressures $p\left(\mathrm{O}_{2}\right)$ associated to of the different oxygen buffer couples as function of annealing temperature. Calculations based on Ellingham diagram $^{[21]}$ (compare Table 1). Dashed line describes maximum reduction temperature used in this work. Inset: Sketch of the annealing procedure.

Table 1: Quantity of metal and oxide powder used for annealing of layers with the four BC combinations. Enthalpy $\Delta H$ and Entropy $\Delta S$ extracted from Reed et al. ${ }^{[13]}$.

\begin{tabular}{|c|c|c|c|c|}
\hline Reaction Equation & Metal Mass & Oxide Mass & $\Delta H$ & $\Delta S$ \\
{$[\mathrm{mg}]$} & {$[\mathrm{mg}]$} & {$[\mathrm{kJ} / \mathrm{mole}]^{[13]}$} & {$[\mathrm{J} / \mathrm{K} / \mathrm{mole}]^{[13]}$} \\
\hline $2 \mathrm{Ni}+\mathrm{O}_{2} \leftrightarrow 2 \mathrm{NiO}$ & $158(78.6)$ & $200(100)$ & -474.43 & 167.2 \\
\hline$\frac{3}{2} \mathrm{Fe}+\mathrm{O}_{2} \leftrightarrow \frac{1}{2} \mathrm{Fe}_{3} \mathrm{O}_{4}$ & $145(72.4)$ & $200(100)$ & -543.40 & 153.0 \\
\hline
\end{tabular}




\begin{tabular}{|c|c|c|c|c|}
\hline$\frac{4}{3} \mathrm{Cr}+\mathrm{O}_{2} \leftrightarrow \frac{2}{3} \mathrm{Cr}_{2} \mathrm{O}_{3}$ & $136.8(68.4)$ & $200(100)$ & -744.04 & 167.2 \\
\hline $2 \mathrm{Mn}+\mathrm{O}_{2} \leftrightarrow 2 \mathrm{MnO}$ & $140(64.5)$ & $190(100)$ & -767.03 & 148.0 \\
\hline
\end{tabular}
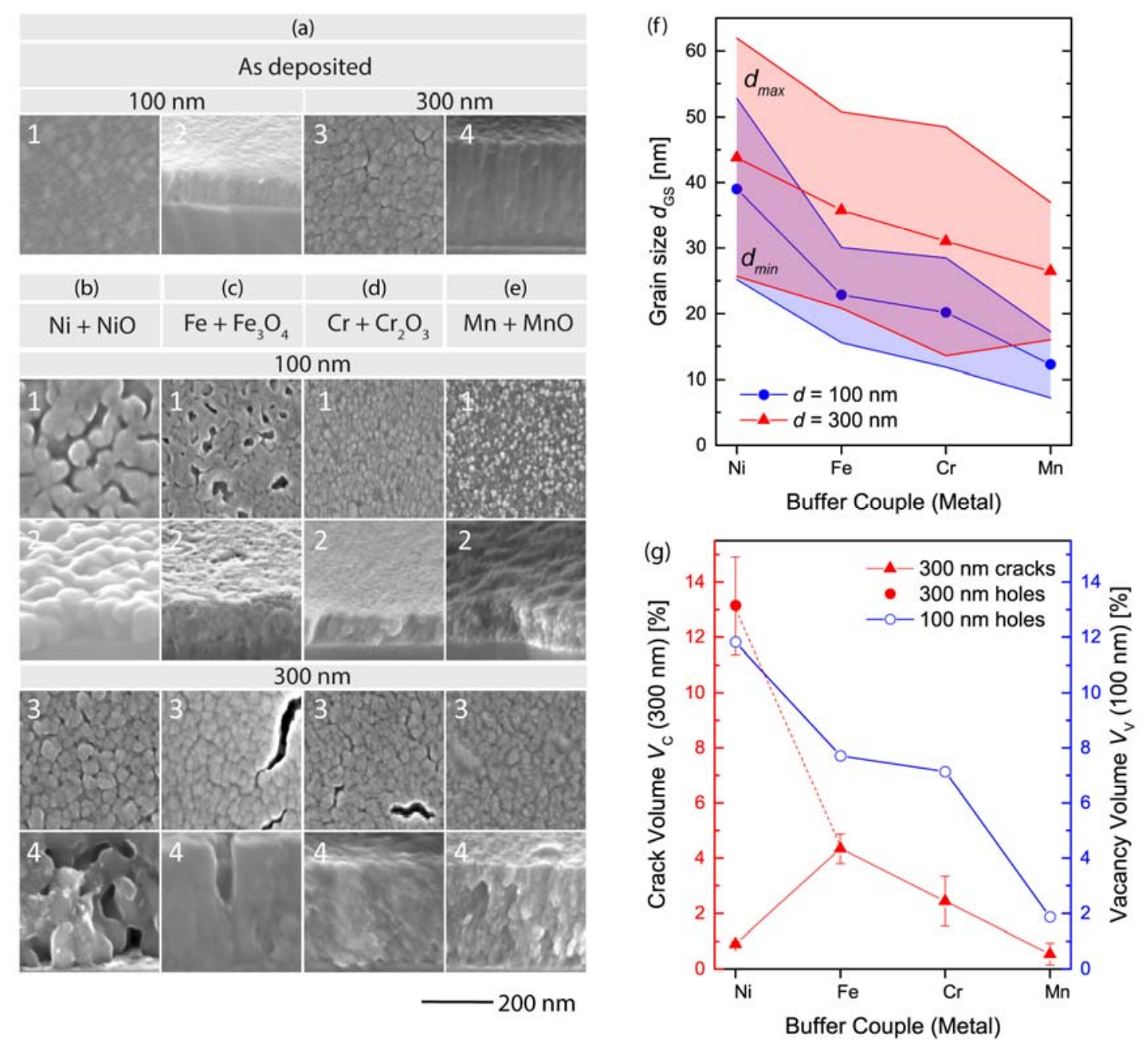

Figure 2 (a): SEM images (top view and cross section) for $\mathrm{V}_{2} \mathrm{O}_{3}$ thin films on silica substrates for pristine amorphous layers ((a1\&a2) $100 \mathrm{~nm}$ and (a3\&a4) $300 \mathrm{~nm}$ ) and layers after anneling with different buffer couples and with different thicknesses (b)-(e): Ni+NiO 100 nm (b1\&b2) \& $300 \mathrm{~nm}(\mathrm{~b} 3 \& b 4), \mathrm{Fe}+\mathrm{Fe}_{3} \mathrm{O}_{4} 100 \mathrm{~nm}(\mathrm{c} 1 \& \mathrm{c2}) \& 300 \mathrm{~nm}(\mathrm{c} 3 \& \mathrm{c} 4), \mathrm{Cr}+\mathrm{Cr}_{2} \mathrm{O}_{3} 100 \mathrm{~nm}(\mathrm{~d} 1 \& \mathrm{~d} 2) \&$ $300 \mathrm{~nm}(\mathrm{~d} 3 \& \mathrm{~d} 4), \mathrm{Mn}+\mathrm{MnO} 100 \mathrm{~nm}(\mathrm{e} 1 \& \mathrm{e} 2)$ \& $300 \mathrm{~nm}$ (e3\&e4). (f): Lateral grain size for 
$100 \mathrm{~nm}$ (blue circles) and $300 \mathrm{~nm}$ (red triangles) $\mathrm{V}_{2} \mathrm{O}_{3}$ thin films with grain size distribution. $(\mathrm{g})$ Evolution of void area(blue circles) and surface crack area (red triangles) for $100 \mathrm{~nm}$ and $300 \mathrm{~nm} \mathrm{~V} \mathrm{O}_{3}$ thin films with error bars.

(a)

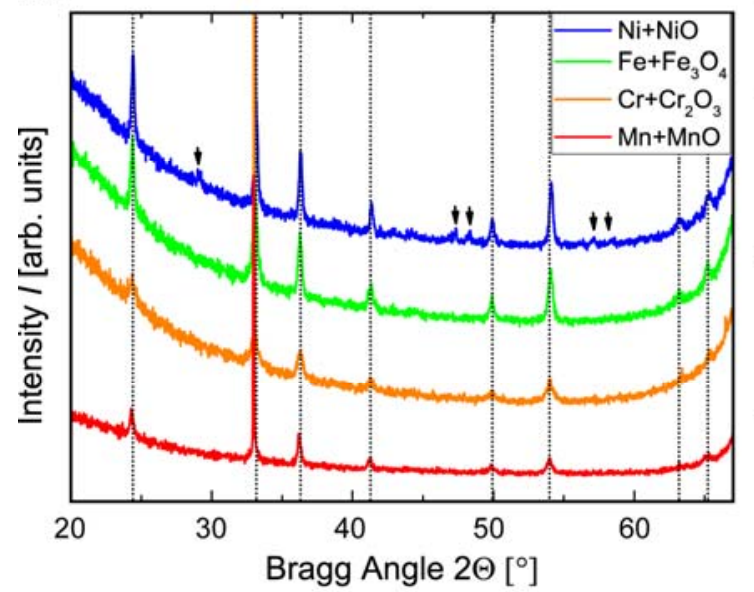

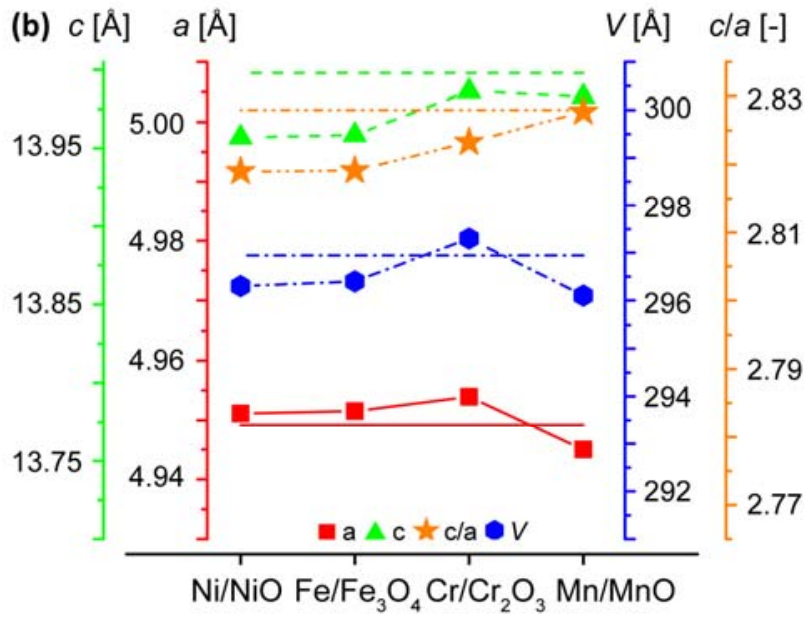

Figure 3 (a): X-ray diffraction patterns in Bragg-Brentano geometry for $300 \mathrm{~nm}$ thick $\mathrm{V}_{2} \mathrm{O}_{3}$ films. All thin films exhibit a corundum $\mathrm{R} \overline{3} \mathrm{c}$ structure corresponding to $\mathrm{V}_{2} \mathrm{O}_{3}$ lattice planes ${ }^{[23]}$ (vertical dashed lines) with an unknown secondary phase indicated by black arrows. (b) Unit cell parameters of $300 \mathrm{~nm}$ thick $\mathrm{V}_{2} \mathrm{O}_{3}$ films after annealing process with different buffer couples: c-parameter (green), a-parameter (red), cell volume $V$ (blue), c/a ratio (orange). Horizontal lines correspond to bulk values ${ }^{[4]}$.

Table 2: Le Bail fitting parameters for $300 \mathrm{~nm}$ thick films with buffer couple type $B C$, reliability factors $R_{\mathrm{p}}$, weighted reliability factors $w R_{\mathrm{p}}$, goodness of fit GOF, cell parameters $a$ and $c$, cell parameter ratio $c / a$ and cell volume $V$.

\begin{tabular}{|l|l|l|l|l|l|l|l|}
\hline $\begin{array}{l}\mathrm{BC} \\
{[\mathrm{nm}]}\end{array}$ & $\mathrm{R}_{\mathrm{p}}[\%]$ & $\begin{array}{l}\mathrm{wR} \mathrm{R}_{\mathrm{p}} \\
{[\%]}\end{array}$ & $\mathrm{GOF}$ & $a[\AA]$ & $c[\AA]$ & $c / a[\AA]$ & $V\left[\AA^{3}\right]$ \\
\hline $\mathrm{Ni}+\mathrm{NiO}$ & 4.93 & 6.66 & 1.18 & 4.9511 & 13.9570 & 2.8190 & 296.3 \\
\hline $\mathrm{Fe}+\mathrm{Fe}_{3} \mathrm{O}_{4}$ & 4.96 & 6.63 & 1.20 & 4.9515 & 13.9587 & 2.8191 & 296.4 \\
\hline $\mathrm{Cr}+\mathrm{Cr}_{2} \mathrm{O}_{3}$ & 4.54 & 5.97 & 1.03 & 4.9539 & 13.9865 & 2.8233 & 297.3 \\
\hline $\mathrm{Mn}+\mathrm{MnO}$ & 4.70 & 6.14 & 1.03 & 4.9450 & 13.9828 & 2.8277 & 296.1 \\
\hline
\end{tabular}


(a)

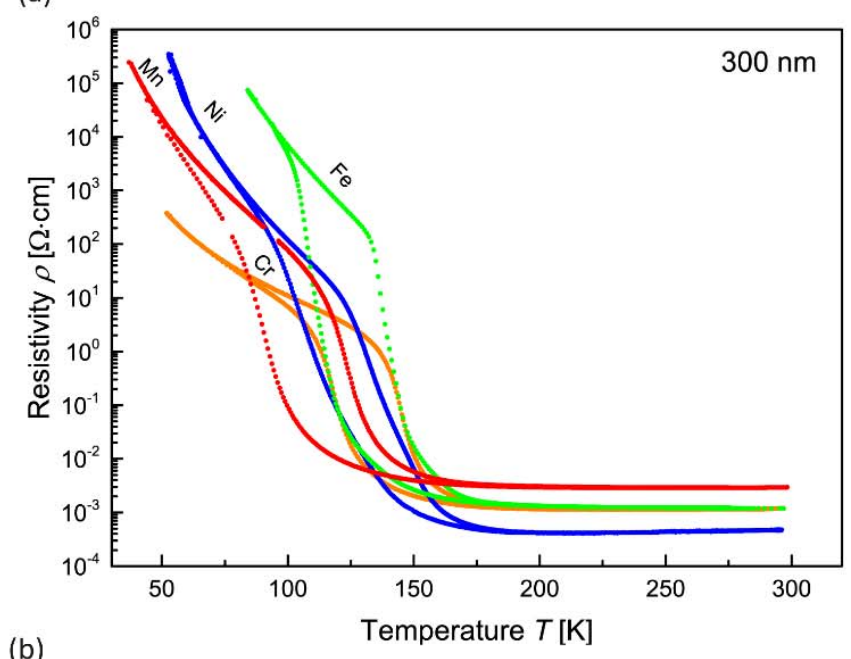

(b)

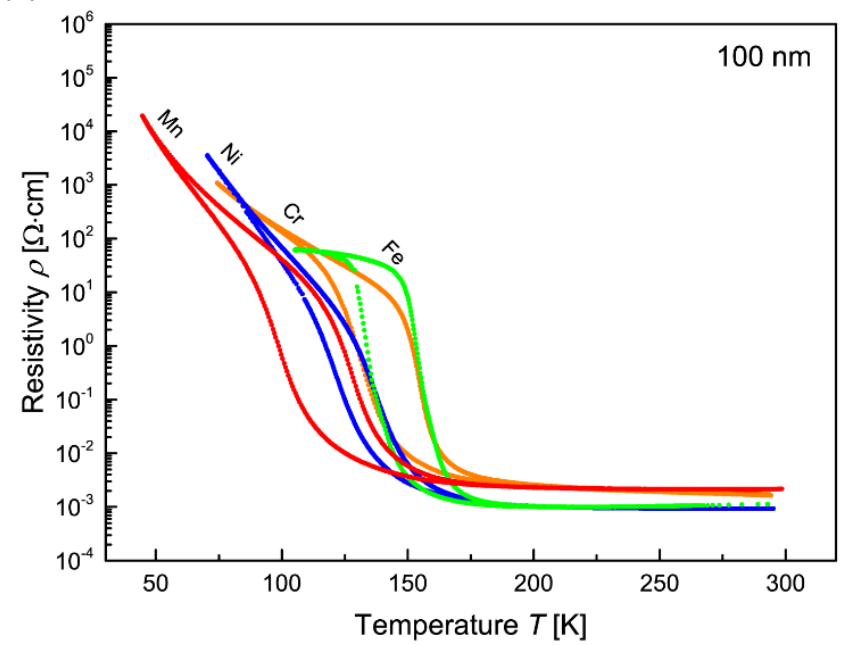

(c)
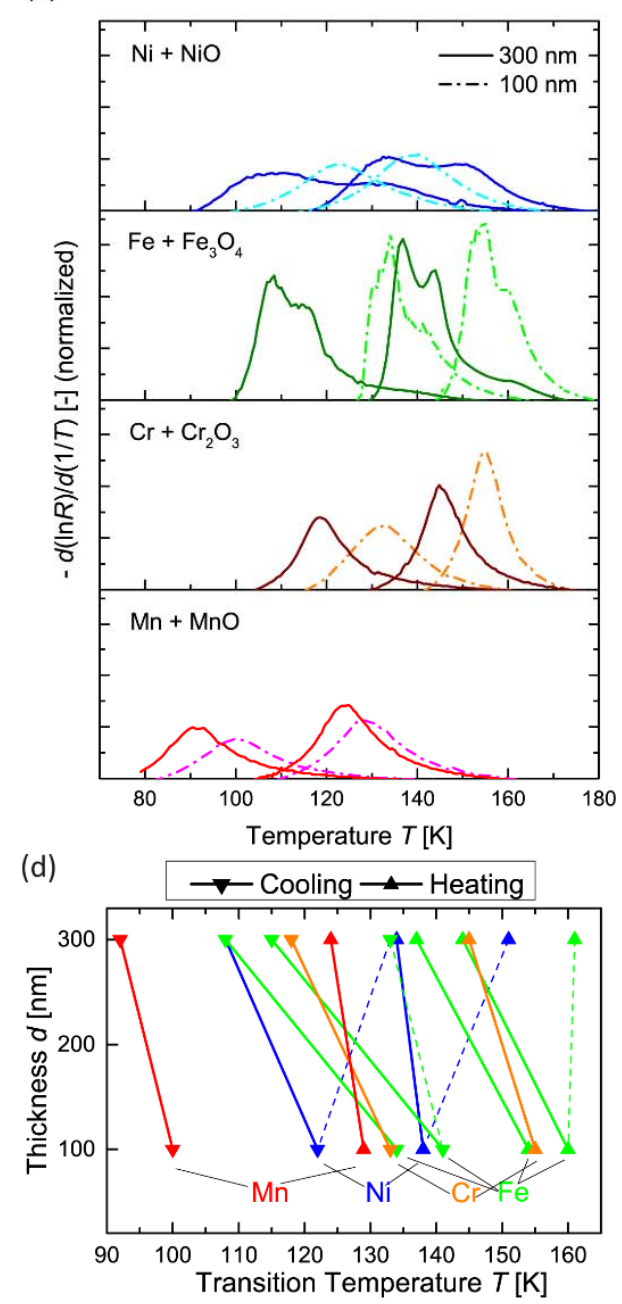

Figure $4(\mathrm{a})$ \&(b): Low temperature electrical transport characteristics of annealed $\mathrm{V}_{2} \mathrm{O}_{3}$ thin films for both thicknesses (a) $300 \mathrm{~nm}$ (b) $100 \mathrm{~nm}$ reduced with the four buffer couples: $\mathrm{Ni}+\mathrm{NiO}$ (blue), $\mathrm{Fe}+\mathrm{Fe}_{3} \mathrm{O}_{4}$ (green), $\mathrm{Cr}+\mathrm{Cr}_{2} \mathrm{O}_{3}$ (orange), $\mathrm{Mn}+\mathrm{MnO}$ (red). (c) Derivative of logarithmic resistance versus inverse temperature for the four used buffer couples and two vanadium oxide thicknesses of $300 \mathrm{~nm}$ and $100 \mathrm{~nm}$. (d) Transition temperatures of cooling (triangles facing down) and heating (triangles facing up) branch for the four buffer couples and two thicknesses. Dashed lines describe additional transition temperatures in more complex derivatives of Ni\&Fe-based BCs (compare (c). 